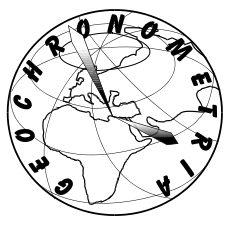

Conference Proceedings of the $12^{\text {th }}$ International Conference "Methods of Absolute Chronology" May 11-13 ${ }^{\text {th }}$ 2016, Gliwice-Paniówki, Poland

\title{
RECURRENCE INTERVAL OF STRONG EARTHQUAKES IN THE SE ALTAI, RUSSIA REVEALED BY TREE-RING ANALYSIS AND RADIOCARBON DATING
}

\author{
ROMAN K. NEPOP ${ }^{1,2}$ and ANNA R. AGATOVA ${ }^{1,2}$ \\ ${ }^{1}$ Sobolev Institute of Geology and Mineralogy, Koptyuga av., 3, Novosibirsk, 630090 Russia \\ ${ }^{2}$ Ural Federal University, Yekaterinburg, Mira str., 19, 620002 Russia
}

Received 28 June 2016

Accepted 23 October 2017

\begin{abstract}
This paper presents the results of paleoseismogeological investigations including tree-ring analysis and radiocarbon dating in pleistoseist zone of the 2003 Chuya earthquake, SE Altai, Russia. Twenty-five radiocarbon dates of previously unknown evidences of prehistoric earthquakes along the fault bounders of the Chagan-Uzun massif, North Chuya and South Chuya ranges are reported. Perspectives of applying dendroseismological approach within the high mountainous seismically active southeastern part of Russian Altai are demonstrated. In addition to estimating the germination ages of trees growing on the bare surfaces of seismically triggered landslides, analysis of wood penetrating injuries in the individual tree ring series was applied for dating paleorock-falls. Analysis of distribution patterns of tree-ring anomalies and injured trees suggests a criterion of recognizing seismic origin of past rock-falls. Dendrochronologically obtained dates of abrupt intensifications of rock-falls can be considered as supposed dates of past earthquakes, which should be verified by alternative proxy data. Obtained results argue for the high regional seismicity in the second half of the Holocene. Strong earthquakes occurred here $\mathrm{AD} 1532$, and 600-700, 1300-1500, 2400-2700, 3400-3700, 3800-4200 cal BP. This data clarifies the chronology of seismic events within the SE Altai. The specified recurrence interval of strong earthquakes is about 400 years during the last 4000 years.
\end{abstract}

Keywords: radiocarbon dating, tree-ring analysis, paleoseismicity, recurrence interval of strong earthquakes, Holocene, SE Altai.

\section{INTRODUCTION}

The evolution of paleoseismogeological studies clearly demonstrates that in order to properly understand the seismic potential of a region, and to assess the associated seismic hazard, extensive studies are necessary to take full advantage from the geological evidence of past

Corresponding author: R. Nepop

e-mail: agatr@mail.ru earthquakes. The period of instrumental seismological observations is insignificant in comparison with the recurrence interval of strong earthquakes. Thus to achieve these goals the historical data are being involved. Paleoseismogeology supplements historical and instrumental records of seismicity by characterizing strong prehistoric earthquakes. It is focused on studying ground effects (both primary - ruptures, and secondary - gravitational deformations (Solonenko, 1973 and McCalpin, 2009)) from past earthquakes preserved in the geologic and geomorphic environment. In this context the recurrence 
interval of strong paleoearthquakes is a critical characteristic. It assumes applying numerical dating techniques for absolute age determination of seismically induced landforms, associated sediments or other evidences of strong past seismic events.

The most direct methods (fault scarp formation applying scarp degradation modeling, cosmogenic surface exposure dating, analysis of scarp soils etc.) return relatively large age uncertainties (McCalpin, 2009). Dating landforms is typically less precise than dating sediments (Burbank and Anderson, 2001 and McCalpin, 2009), although relatively precise indirect dating of associated deposits also may not provide close constraints of ancient seismic events. Today radiocarbon analysis is the most exploitable and widely applicable technique in paleoseismogeology. It allows determining the age of soils, tree fragments and other organic materials which were deformed and/or buried during the earthquake.

Generally, the application of the radiocarbon method is limited by $\sim 50 \mathrm{ka}$ but some problems occurred while using this technique for dating recent (about $2 \mathrm{ka}$ ) seismic events due to high relative methodological error and presence of several "plateaus" at the calibration curve which make it difficult the age correlation with the calendar scale (Wagner, 1998). In case of spreading forest vegetation in seismically active areas tree-ring analysis can be used as an additional or alternative approach. It has a great potential due to utmost precision of dating annual and sometimes even seasonal resolution, which is an obvious advantage in comparison with the radiocarbon analysis.

Seismically induced surface processes can affect vital activity of trees and cause their reaction on environmental changes. Thus rings of trees - witnesses of seismic events, could be potentially valuable nature archive containing both the evidence for the earthquake and its age. This forms the basis for precise dating seismically induced geomorphic processes, landforms and sediments produced or deformed by earthquakes (Jacoby, 1997). Tree rings can record evidences of earthquakes associated with tectonic deformations or ruptures (primary effects), seismogravitational deformations or mass movement processes (secondary effects), and various other seismically induced environmental changes (side effects) (Table 1). Some most exploitable in paleoseismogeological investigations aspects of tree-ring analysis are discussed in literature (Jacoby, 1997; McCalpin, 2009 and others).

For dating ruptures and tectonic scarps formation analysis of splitting tree-trunks and tilting stems could be applied (Page, 1970; Ruzhich et al., 1982 and Bekker, 2004).

Regarding the earthquake induced mass movement processes the germination age of forest vegetation growing on the bare surface (estimated by the age of the eldest tree) returns the upper possible time of landslide formation. The direct dates of landslide events can be obtained by analyzing buried dead trees and/or reaction wood formation from the living ones as a response on the stem inclination. Subsequent growth of the tilted tree will aim to restore the trunk's vertical position. Thus eccentric tree-ring growth after a tilting event can be dated (Sheppard and Jacoby, 1989 and Stoffel and Corona, 2014). Wood penetrating injuries and scars are also a common feature in trees affected by earthquake induced rock-falls. Callus tissue formation is commonly regarded as a reliable indicator of past geomorphic process activity (Lundström et al., 2009 and Trappmann and Stoffel,

Table 1. Application of tree-ring analysis to earthquake studies. Direct and indirect effects are presented under a "process-effect-response" model. Various aspects of studying growth disturbances in trees affected by geomorphic processes are analyzed in (Stoffel and Bollschweiler, 2008) and application of tree-ring analysis to paleoseismology is discussed in detail by Jacoby (1997).

\begin{tabular}{|c|c|c|}
\hline Process & Effect & Response \\
\hline \multicolumn{3}{|c|}{ Primary earthquake effects (tectonic deformations) } \\
\hline rupturing & splitting the trunk, root system damage & suppression, missed rings, mortality \\
\hline tectonic scarp formation & tilting of stems & reaction wood formation \\
\hline \multicolumn{3}{|c|}{ Secondary earthquake effects (mass movements) } \\
\hline slope failures, devastating mass movements & elimination of the entire forest stand & recolonization of bare surface \\
\hline \multirow{5}{*}{$\begin{array}{l}\text { landslides, } \\
\text { rock falls, } \\
\text { debris flows }\end{array}$} & tilting of stems & reaction wood formation \\
\hline & stem burial & $\begin{array}{c}\text { suppression, mortality, } \\
\text { exceptionally - growth increase in case of rich } \\
\text { nutrition and water supply }\end{array}$ \\
\hline & root exposure & growth suppression, mortality \\
\hline & wood penetrating injuries, scars & callus tissue formation and overgrowing the wound \\
\hline & decapitation, elimination of branches & growth suppression \\
\hline \multicolumn{3}{|c|}{ Side effects } \\
\hline ground shaking & decapitation, root system and major limb damage & suppression, missed rings, mortality \\
\hline change in hydrology & change in water table & suppression, growth increase \\
\hline various earthquake induced surface processes & elimination of neighboring trees & the growth release in survivor trees \\
\hline
\end{tabular}


2013). Partial stem burial with debris leads to a reduced activity of the roots, and to additional mechanical pressure of slope material (Hupp et al., 1987 and Friedman et al., 2005). The resulted growth suppression is indicated by reduction in the annual ring widths and therefore can be dated (Stoffel and Corona, 2014). Exceptionally the growth increase is possible in case of rich nutrition and water supply (Strunk, 1997). Roots exposure induced by slope mass movements leads to shortage of water and nutrient supply and, therefore, to suppressed tree growth and the formation of narrow rings in the stem (McAuliffe et al., 2006). In case of decapitation or the removal of branches, as a result of seismically triggered rock-falls, trees react with distinct radial growth suppression.

Various side effects of strong earthquakes such as ground shaking, hydrological changes etc. can also affect the forest vegetation. The negative impact on their living conditions can stimulate growth suppression, missed rings, and even mortality of trees. Sometimes the elimination of neighboring trees can result in a new less competitive environment for survivor ones. The survival trees can respond on these favorable changes with growth increase and wider tree rings (Strunk, 1997).

This paper presents the results of paleoseismogeological investigations in the pleistoseist zone of the 2003 Chuya earthquake $\left(M_{S}=7.3\right)$ that stroke southeastern part of Russian Altai. During this strongest historical seismic event the southern fault boundary between Kurai-Chuya system of intermountain depressions and framing ridges, as well as fault boundaries of the Chagan-Uzun massif (an independent neotectonic block, which separates these depressions) was reactivated. The studied sites are located in the northern and southern bounders of this massif, which is one of the major seismogenic structure in the region. We report new radiocarbon dates related to the geological evidences, which define the chronology of strong prehistoric earthquakes in the region. These data together with the results of tree-ring analysis and previously published radiocarbon dates allow specifying the recurrence interval of strong earthquakes for the last 4000 years.

\section{STUDY AREA}

\section{Geological settings and evidences of high regional seismicity}

The Altai Mountains are the northern part of the Central Asia collision belt (Fig. 1). They stretch northwest more than $1500 \mathrm{~km}$ across the borders of Mongolia, China, Kazakhstan and Russia, and form a wedge shape narrowest in the southeast and widest in the northwest. Elevation increases in the opposite direction from 400 to more than $4000 \mathrm{~m}$ a.s.l. The neotectonic structure of the Altai Cenozoic uplift is formed by four NW trending dextral strike-slip fault zones. These major regional faults, together with feathering ones, divide Earth crust

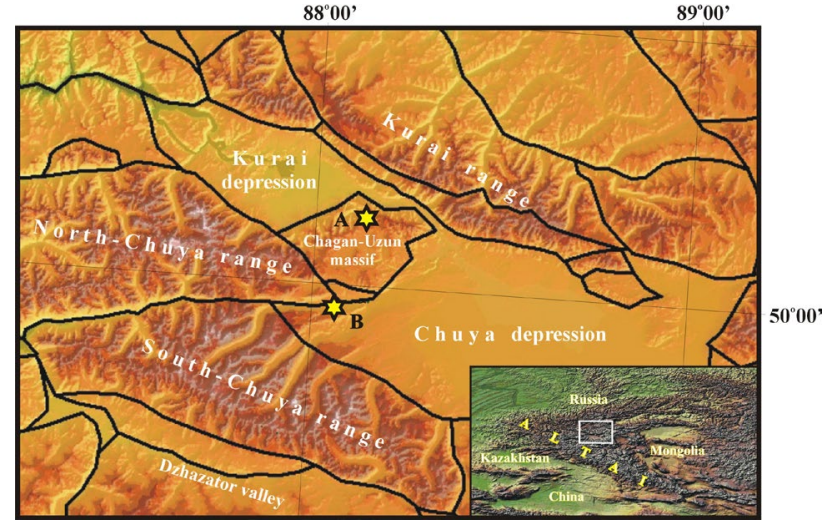

Fig. 1. Study area. Inset indicates the location of the SE Altai within the Altai Mountains. Neotectonic structure presented after Novikov, 2004. The studied sites in the Arydjan A) and Taldura B) valleys are shown with diamond.

into separate tectonic blocks - ridges and intermountain depressions (Novikov, 2004).

The high-mountain southeastern part of the Russian Altai (SE Altai) is the northern extension of Mongolian Altai which is known by its high seismicity. Within the neotectonic structure of the Altai Mountains, SE Altai is a transpressional zone formed due to oblique thrusting. Significant lithosphere destruction and block movement along the sub-latitudinal reverse faults and thrusts take place here.

The SE Altai is the highest part of Russian Altai. It includes the Chuya and Kurai intermountain depressions and framing ridges. Bottoms of the Chuya and Kurai intermountain depressions are located at about 17501900 and $1500-1600 \mathrm{~m}$ a.s.l. correspondingly, with altitudes of framing ridges up to $3500-4200 \mathrm{~m}$ a.s.l. These depressions are separated by the Chagan-Uzun massif with the highest Sukor peak (2926 m a.s.l.) in its northwestern part. Developing presently as a single structure the Chagan-Uzun massif together with the western part of the Chuya intermountain depression is characterized by the largest rates of vertical movement $7.84-8.00 \mathrm{~mm} \mathrm{a}^{-1}$ within the whole Chuya river basin (Rogozhin and Platonova, 2002). Numerous large seismically induced paleolandslides and rock-falls, that mark fault boundaries of the Chagan-Uzun massif, as well as smaller blocks of its inner structure, provide evidence for its high neotectonic activity and make it one of the major seismogenic structures in the region (Rogozhin and Platonova, 2002; Emanov et al., 2009 and Agatova et al., 2014b).

The high seismicity of neighboring Mongolian Altai (Zhalkovsky and Muchnaya, 1975 and Rogozhin et al., 2013) was one of the reasons to mark the SE Altai as the most seismically active part of the Russian Altai. Almost its whole territory is characterized by seismic intensity of VIII point according to MSK-64 (Medvedev-SponheuerKarnik macroseismic intensity scale). The intensity IX zone was restricted to a small area including the south- 
western part of the Chuya depression (Zhalkovsky et al., 1995). It was outlined proceeding from the seismic origin of numerous landslides in the Chagan-Uzun and Dzhazater river basins and from the high seismicity of neighboring areas of Mongolia, shocked by several great seismic events in the $20^{\text {th }}$ century (Devyatkin, 1965).

High seismicity of the SE Altai is evidenced by paleoruptures, numerous large Holocene earthquake induced landslides, and seismic convolutions in soft sediments (Fig. 2) (Butvilovsky, 1993; Rogozhin and Platonova, 2002; Rogozhin et al., 2007; Deev et al., 2009 and Agatova et al., 2006, 2014a). Recently it was supported by the 2003 Chuya earthquake $\left(M_{S}=7.3\right)$. This strongest historical seismic event generated a complicated NW trending system of primary seismotectonic deformations of about $70 \mathrm{~km}$ in length. Main rupture is a dextral strike slip fault with a horizontal displacement up to $2 \mathrm{~m}$, and subsidiary branch faults of reverse and dextral strike slip kinematics (Rogozhin et al., 2007). Landslide on the right

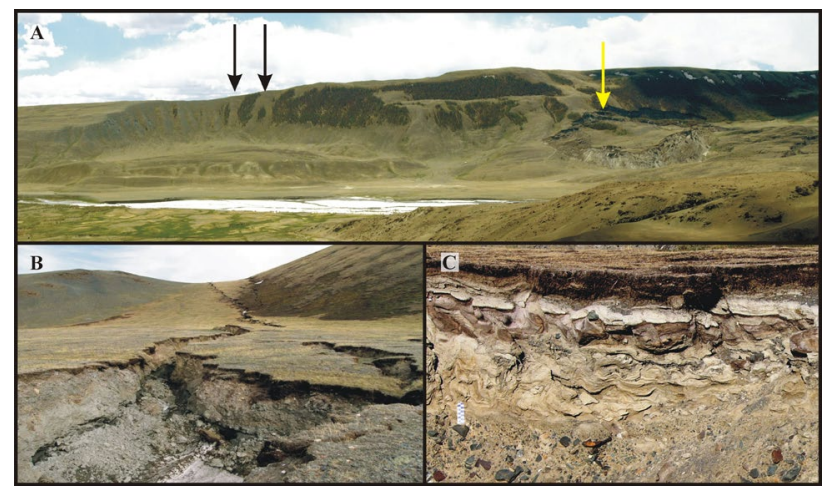

Fig. 2. Evidences of high regional seismicity.

A) Seismically induced landslides in Taldura valley (T1 in Fig. 4). Black arrows show paleolanslide and light arrow - the largest landslide triggered by the 2003 Chuya earthquake. B) Ruptures of the 2003 Chuya earthquake in the Uzuk stow (U in Fig. 4) going along saddleback of tectonic origin. C) Holocene seismic convolutions in soft sediments in Taldura valley (T1 in Fig. 4).

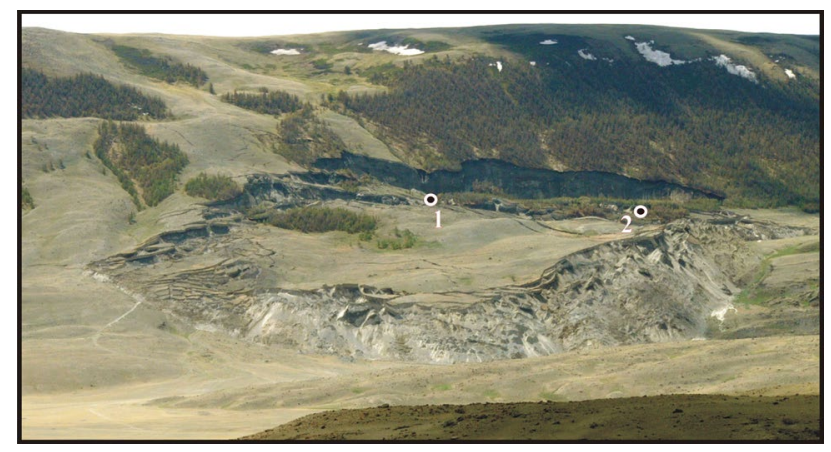

Fig. 3. The largest landslide triggered by the 2003 Chuya earthquake in Taldura valley (T1 in Fig. 4). Numbers indicate location of studied outcrops.
Taldura river bank is the largest seismogravitational deformation triggered by this earthquake (Fig. 3).

Widely distributed unconsolidated Cenozoic sediments provide favorable conditions to produce earthquake induced landslides. Rockslides are mainly distributed within mountain ranges, framing Chuya and Kurai intermountain depressions. In contrast, the vast extent of the Neogene lacustrine and Pleistocene moraine deposits in the most active areas of the depression-range transition within the Chuya basin provides geological conditions for developing deep seated landslides.

It should be mentioned that generally all types of landslides triggered by earthquakes may also occur without seismic triggering (Keefer, 2002). Strong earthquakes are the leading factor in the generation of giant landslides in the SE Altai. Our field observations of the impact of strong modern and prehistoric earthquakes reveal several criteria that indicate seismic origin of observed ground failures within studied area (Nepop and Agatova, 2008): $i$ ) the great extent of ground failures upon strongly cemented Neogene and Pleistocene permafrost sediments, as well as high concentration of numerous seismically induced landforms (both huge and small ones) within the same area; ii) location of the landslides in the most active areas at the basin-range transition along fault boundaries of landforms and fault crossings; iii) absence of correlation between location of landslides and exposure of slopes to insolation, their age and rock composition; and iv) conjunction (relative position) of landslide locations with the ruptures on the watersheds and valley slopes. It should be also noted that location of all giant landslides in an area of extremely dry climate rules out their rainfall or a snowmelt trigger.

\section{Regional climate and potential of applying tree-ring analysis in the SE Altai}

Contemporary climate in the region is determined by its intracontinental position, with the main moisture transfer from the west (Atlantic Ocean), and to a lesser degree from the north (Arctic), with a dominant influence of the Mongolian anticyclone, giving rise to increasing aridity southeastwards and complicated latitude-longitude orographic climatic zoning. The SE Altai is characterized by extreme ultra continental cryoarid permafrost affected environment. The mean annual precipitation within the SE Altai is less than $200 \mathrm{~mm}$ in the floor of intermountain depressions, increasing with height. The mean annual precipitation near the snow line decreases along the $\mathrm{W}-\mathrm{E}$ axis from $2000 \mathrm{~mm}$ (in the western part of the Katun range) to less than $500 \mathrm{~mm}$ in the Chikhachev range near the Mongolian border (Narozny and Osipov, 1999).

In the western part the stony steppe on the floor of the Kurai depression grades into taiga vegetation on the range's slopes. In the western mountains flanking the Chuya depression, forests have an insular distribution, vanishing completely in the southeastern part. The plateau-toppled highlands are covered by alpine meadows. 
The higher topographic belt is represented by alpine landscapes with mountain tundra and tundra-steppe vegetation changing with height into a glacial zone.

Under arid conditions, local orographic climate factors, first of all, the slope exposure, mainly control tree ring characteristics and tree growth near the upper timber limit in the region. There is a good correlation among growth indexes of all obtained regional tree-ring chronologies (TRC), located above $2200 \mathrm{~m}$ a.s.l., as well as a good correlation with tree-ring chronologies for neighboring areas of Tuva (TRC "Mongun") and Mongolia (TRC "Khalzam Khamar") (Tainik et al., 2015). Radial growth of trees in the region is affected by early summer (June or July) temperatures (Tainik et al., 2015; Barinov et al., 2016). Today a number of TRC are developed for the SE Altai: 1105-year TRC "Aktru" (Ovchinnikov et al., 2002), 1896-year TRC "Jelo" (Myglan et al., 2009) (both on Larix sibirica Ledeb); 1241-year TRC on Pinus sibirica Du Tour (Nazarov and Myglan, 2012). All these chronologies characterize environmental conditions of tree growth within the northern slope of the North Chuya range.

Generally, distribution of forest vegetation and the age of trees are the main limitations of applying tree-ring analysis in paleoseismogeological investigations. This technique is a promising tool for dating seismically induced landforms within the SE Altai due to several reasons: $i$ ) seismically induced slope processes occur in the forest stand zone in immediate vicinity with the modern upper timber limit (at this altitude the tree-ring growth is mainly controlled by climate which is favorable for building long TRC); ii) arid climate promotes good preservation of wood (up to two thousand years on stone surfaces); iii) a number of long absolute TRC has been developed for the SE Altai and adjusted Tuva region; iv) the 2003 Chuya earthquake gives unique opportunity to analyze the distribution patterns of wood penetrating injuries and other growth anomalies of specifically seismic origin.

\section{History of paleoseismogeological investigations}

First historic accounts of earthquakes within the Russian Altai are dated back to the $18^{\text {th }}$ century and the first Earthquake Catalog of the Russian Empire, which mentioned Altai seismic events, was issued in the $19^{\text {th }}$ century. The earliest instrumental seismic data had come from remote stations that provided reliable records of quite strong $(M>5)$ earthquakes (Kirnos et al., 1961) before a regional seismological network was set up in 1962 (Zhalkovsky et al., 1995). Numerous instrumental records of $K=7-14$ seismic events (corresponding $M \sim 1.66-$ 5.5) collected by the regional network allowed calculating location of earthquake epicenters, estimating their magnitudes, and making seismic zoning (Zhalkovsky and Muchnaya, 1978). Applying these results together with geological and paleoseismological data the recurrence interval 1-3 ka of strong Holocene earthquakes for the SE Altai was suggested (Zhalkovsky and Muchnaya, 1978).
The idea of high regional seismicity of the SE Altai later was supported by the results of seismotectonic investigations (Reisner and Ioganson, 1996). The first extensive paleoseismogeological researches including numerous radiocarbon dating within the SE Altai were carried out before the 2003 Chuya earthquake (Rogozhin and Platonova, 2002), when a number of previously unknown strong past seismic events was reported.

For the first time in paleoseismogeological researches within the SE Altai Rogozhin introduced routine application of radiocarbon analysis for numerical age estimations of seismically deformed/cut paleosoils, organic material buried in colluvium wedges and pressure ridges, and for dating other effects of past earthquakes (Rogozhin and Platonova, 2002 and Rogozhin et al., 2007, 2008). A broad set of obtained radiocarbon dates allowed specifying the recurrence interval of strong earthquakes in the region - 500-900 years for the last 9 ka (Rogozhin et al., 2007, 2008).

In our paleoseismogeological investigations within the SE Altai we complete existing radiocarbon dataset and for the first time utilize dendroseismological approach (Agatova et al., 2014b).

\section{METHODS}

Detailed geomorphological and paleoseismogeological investigations and process analyses were based on interpretation of aerial photographs, Landsat-TM images, topographic maps (scale of 1:25000), and field investigations including mapping of landforms and deposits of different genesis.

Radiocarbon dating was done in the Cenozoic Geochronology Center SB RAS, Novosibirsk, and in the Institute of Geography RAS, Moscow. Determination of carbon residual activity in both laboratories was done with the QUANTULUS-1220. The conventional radiocarbon ages were calibrated applying OxCal v.4.3.2 program (Bronk Ramsey, 2009) with the IntCal13 calibration data set (Reimer et al., 2013). In the text calibrated results are reported as intervals at $95.4 \%$ significance levels.

For making dendroseismological investigations local TRC was developed. Sampling was carried out with the main goal of building the longest possible TRC and obtaining the representative sample collection of wood penetrating injuries. Samples were taken from trees (both living and dead ones) located on the surfaces of the talus fans and landslides near the scarps or most active talus channels. Trees with traumas on the slope facing and lateral sides of the trunks (affected by frontal and tangent impact of falling stones) were selected among the standing ones. Cores were taken from living trees and discs from dead ones. In order to provide reliable dating additional discs were collected from the uninjured parts of tree trunks as well as cores from undamaged living trees.

Preliminary sample preparation and dendrochronological analysis was carried out in the Laboratory of natural 
science methods, Siberian Federal University, Krasnoyarsk. The standard procedure of building the tree ring chronology (Shiyatov et al., 2000) on Pinus Sibirica Du Tour was applied. Measurements of radial growth for each sample were made on two and more radii applying LINTAB 5 equipment with an accuracy of $0.01 \mathrm{~mm}$. Tree ring series were dated by combining cross-correlation analysis (in the special DPL software (Holmes, 1983)) and graphical cross dating in the TSAP system V3.5 software (Rinn, 1996) with a visual control of variability curves. The age trend was removed using standard procedure (Fritts, 1976) with a negative exponent and spline ( $2 / 3$ of the length of each series) in the ARSTAN program (Cook and Krusic, 2008). Tree ring width measurements of several samples collected from the same tree were brought into generalized series. Thus finally every tree was represented by a single tree-ring series.

The germination ages of trees growing on the bare surfaces of earthquake triggered landslides were calculated, applying age correction for colonization time gap and time of surface stabilization. Besides estimating the germination ages and assessing the minimal possible age of landforms, tree-ring analyses was also applied for estimating the age of earthquakes occurred already after forest regeneration on the surface of these landslides. We suppose that for trees (both dead and living ones) located near the scarps and talus fans, wood penetrating injures could be caused by earthquake induced rock falls as it was during the 2003 Chuya earthquake. Developing local tree ring chronology gives the opportunity to date such events.

The suggested approach implies analysis of wood penetrating injuries in the individual tree ring series for identification and dating of earthquake triggered paleorock-falls. As well as the number of such anomalies, the simultaneity of injuries sustained by several trees growing on different earthquake induced landslides was taken as a criterion of their seismic origin. The accuracy of this approach was supported by analysis of wood penetrating injuries caused by the 2003 Chuya earthquake induced rock-falls. Growth anomalies (disturbance of the tree ring structure) were visually determined with the stereomicroscope and dated.

It should be noted that besides earthquake triggered rock-falls there are climatically driven ones when heavy rains or snow melting act as a trigger. Thus determination the seismic origin of rock-falls plays a crucial role. We suggest that, similarly to the 2003 Chuya earthquake, the number and simultaneity of wood penetrating injuries sustained by many trees grown in different parts of an area affected by seismic shock could be such criteria. It should be emphasized that even after that, the dendrochronologically obtained dates of abrupt intensifications of rock-falls are just supposed dates of earthquakes, which should be verified by alternative proxy data.

\section{RESULTS}

Our paleoseismogeological researches were focused on the pleistoseist zone of the 2003 Chuya earthquake. Newly arisen and renewed scarps and ruptures gave a unique opportunity to study previously unknown evidences of strong prehistoric seismic events. Witnesses of several events were found in sediments of the largest landslide triggered by the 2003 Chuya earthquake and in Taldura river valley (southward of the Chagan-Uzun massif) (Fig. 4 - T1).

Dendroseismological investigations were conducted within two largest landslides (located at 2250-2200 and 2170-2130 $\mathrm{m}$ a.s.l. in the northern part of the ChaganUzun massif (Fig. 4 - A)) from the complex of earthquake triggered landslides in the Arydjan valley (Fig. 5) (Agatova et al., 2014b). A reactivated ancient fault, which laid the foundation of the head of Arydjan valley, formed main scarps of these landslides.

High concentration of numerous seismically induced landforms (both large and small ones) within the same area; absence of correlation between location of landslides and exposure of slopes to insolation, as well as between age of deposits and their rock composition; correspondence of landslides to fault boundaries of landforms and fault crossings; conjunction of landslide locations with the ruptures on the watersheds and valley slopes argue for the seismic origin of the studied landslides.

Siberian pine (Pinus sibirica Du Tour) is the main forest forming tree species at this altitude in the Arydjan valley. Single trees settled the surface of taluses and rockstreams leaned on landslides. The upper timber limit in this valley extends slightly above the landslides but the scarp of the upstream landslide with the height of about $150-170 \mathrm{~m}$ is not settled by trees due to slope steepness and active taluses. More gentle main scarp of the older downstream landslide is settled by single trees.

As a result of precedes geomorphological study, collecting and culling the samples, altogether 61 discs (49 from the downstream landslide and 12 from the upstream one) from the 36 dead trees (30 from the downstream landslide and 6 from the upstream one) with the traumatic traces were analyzed. Utilizing discs and cores collected from trees, which were not affected by seismic shocks, the local 1154-years (AD 856-2009) TRC on Pinus sibirica Du Tour was built (Fig. 6), and verified by the "Jelo" tree-ring chronology (Agatova et al., 2014b). This local TRC has provided the dendrochronological dating of revealed wood penetrating injuries.

The year of birth of the eldest examined trees which colonized the surface of the talus fans covering landslide bodies is $\mathrm{AD} 1069$ and $\mathrm{AD} 856$ for the upstream and downstream landslides respectively. In order to estimate the time of creation of earthquake triggered landslides in addition to the germination ages of trees growing on their surfaces, the colonization time gap (no less than 50-100 

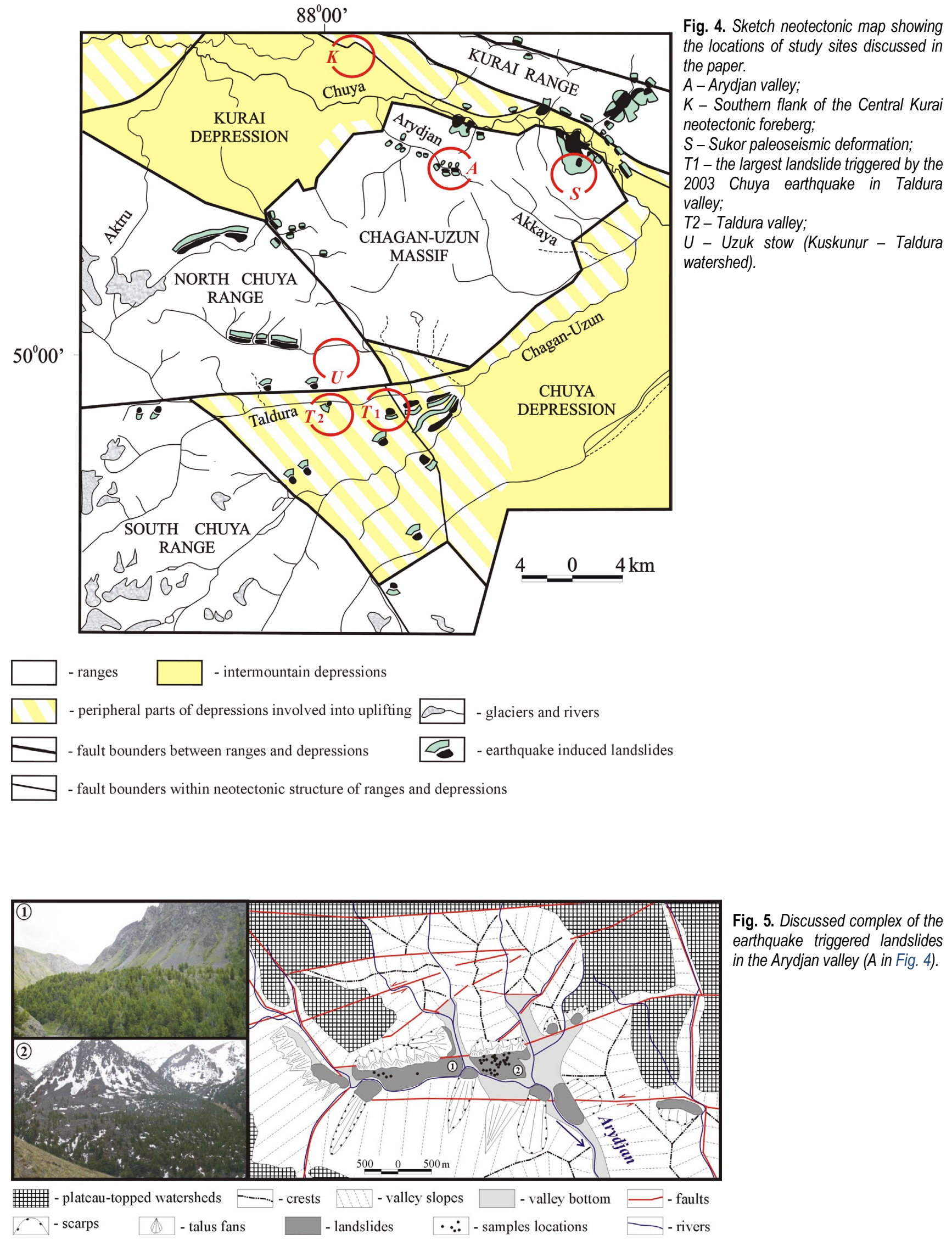

Fig. 5. Discussed complex of the earthquake triggered landslides in the Arydjan valley (A in Fig. 4). 

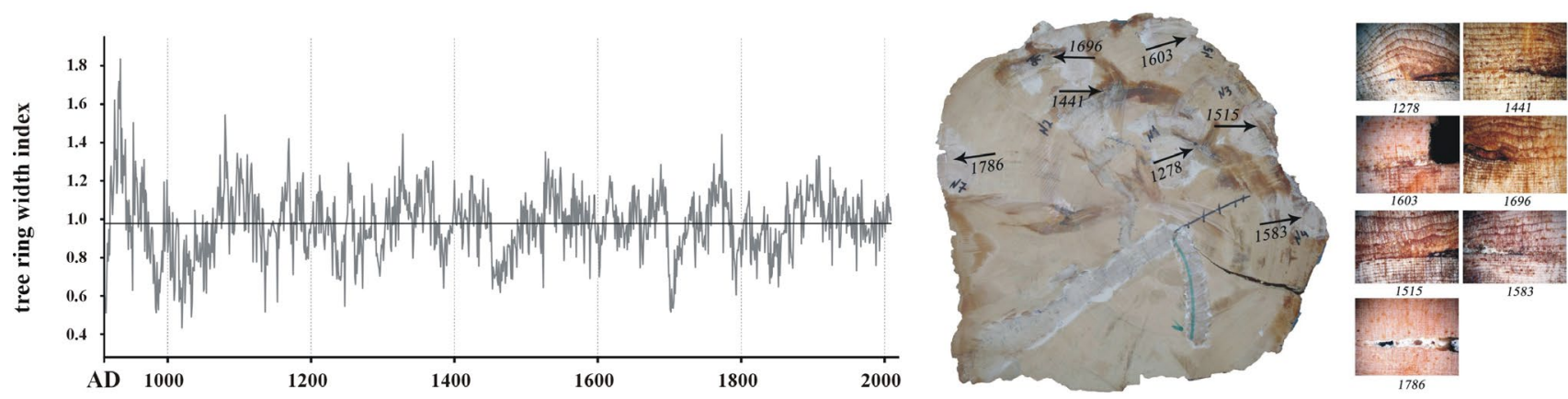

Fig. 6. Local 1154-years (AD 856-2009) TRC on Pinus sibirica Du Tour build for Arydjan valley (Agatova et al., 2014b). On the left - tree-ring growth index. In the center, one of collected discs demonstrates numerous wood penetrating injurious on the slope facing and lateral sides of the trunks (photo made by Barinov V.V.). On the right - anomalies of tree-rings (callus tissue) is a reaction on frontal and tangent impact of falling stones (photo made by Barinov V.V.).

years as it was evidenced by germination ages of trees that settled the LIA moraines in the SE Altai (Okishev, 1982)) and the formation time of talus fans covered landslide bodies, as well as surface stabilization period, should be taken into consideration. Due to these reasons the applied age correction can reach two centuries. Thus, it could be asserted that by AD 600-700 the studied seismically triggered landslides in the Arydjan valley had been existed. The currently available data do not allow clearly distinguish the time of landslides formation.

From 120 traumatic injuries of tree rings, three and more coincide into the years 1316, 1422, 1532 and 2003 (Agatova et al., 2014b). At the same time numerous wood penetrating injuries dated by AD 1532 are indicated for trees grown at both landslides and are displayed at various heights of tree trunks. This fact can imply a high magnitude of a medieval seismic event or/and its nearby epicenter location. Same patterns of wood penetrating injuries caused by rock-falls, triggered by the 2003 Chuya earthquake with its epicenter located on the southern border of the Chagan-Uzun massif, allow us to assume that a strong earthquake struck SE Altai in 1532. Most likely, as in 2003, in 1532 the fault boundaries of the Chagan-Uzun massif were reactivated. The expected date of this medieval seismic event was later verified by radiocarbon dating.
In addition to dendroseismological investigations the radiocarbon dating of earthquake induced landforms and seismically affected sediments was applied. Twenty-five radiocarbon ages were obtained for previously unknown effects of prehistoric earthquakes located along fault boundary between Chuya depression and North Chuya range, southward of the Chagan-Uzun massif (Table 2).

Most samples were collected in newly arisen outcrops produced within the largest landslide triggered by the 2003 Chuya earthquake in the Taldura valley. These are evidences of past seismic events: cut paleosoils and peat layers, redeposited fragments of charcoals resulted in inversion of radiocarbon dates in outcrops, seismic convolutions in sediments of ancient lakes, which was developed in the same manner as modern lake in the back area of recently triggered landslide.

The ages of seismically cut fossil soils with wood/charcoal fragments return the low possible date of seismic event while overlaid undistorted layers give information about its upper possible date. Thus obtained radiocarbon chronology from the newly arisen outcrop in the proximal part of the earthquake triggered landslide in the Taldura valley (Fig. 7; Fig. 3, location 1) supports the expected date of the 1532 seismic event. The ages of seismically deformed fossil soil and buried peat layer are 2360-2110 cal BP (IGAN 4090) and 970-730 cal BP
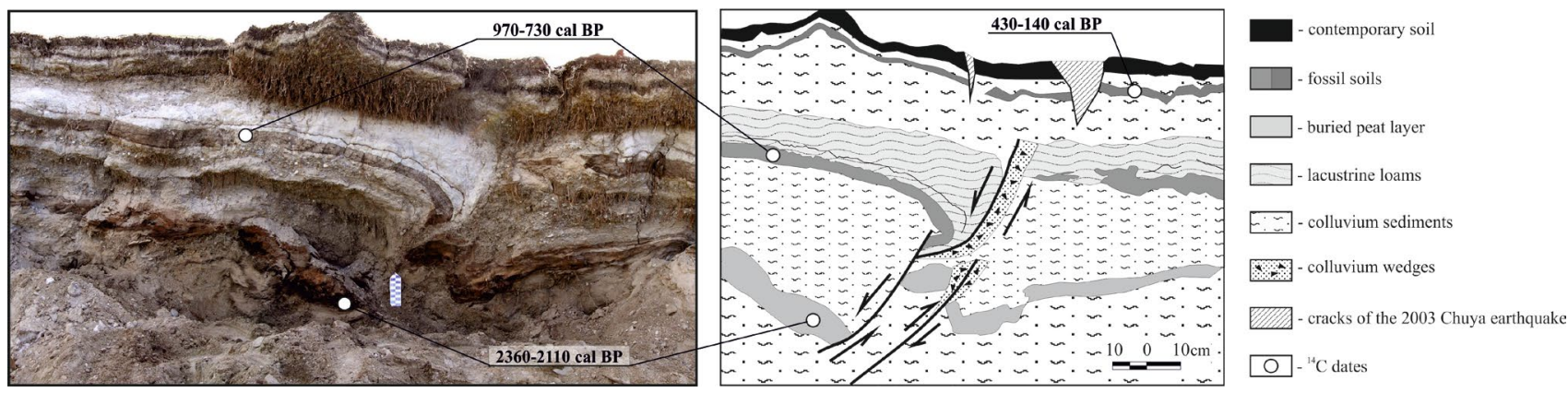

Fig. 7. Newly arisen outcrop in one of the scarps of the largest landslide triggered by the 2003 Chuya earthquake in the Taldura valley (location 1 in Fig. 3). 
Table 2. Radiocarbon dates used for estimating the recurrence interval of strong prehistoric earthquakes in the SE Altai.

\begin{tabular}{|c|c|c|c|c|c|c|}
\hline \multirow[b]{2}{*}{$\begin{array}{l}\text { Sample } \\
\text { Lab. cod }\end{array}$} & \multirow[b]{2}{*}{$\begin{array}{l}\text { Location } \\
\text { Fig. } 4\end{array}$} & \multirow[b]{2}{*}{ Sample type } & \multirow[b]{2}{*}{$\begin{array}{l}{ }^{14} \mathrm{C} \mathrm{age}{ }^{*} \\
(\mathrm{BP})\end{array}$} & \multicolumn{2}{|c|}{ Calibrated age (cal BP) } & \multirow[b]{2}{*}{ Interpretation } \\
\hline & & & & $\begin{array}{c}\text { Significance level } \\
68.2 \%\end{array}$ & $\begin{array}{c}\text { Significance level } \\
95.4 \%\end{array}$ & \\
\hline $\begin{array}{l}\text { IGAN } \\
4090\end{array}$ & $\mathrm{~T} 1$ & $\begin{array}{c}\text { seismically cut fossil soil exhumed } \\
\text { in rupture of the } 2003 \text { Chuya } \\
\text { earthquake }\end{array}$ & $\begin{array}{c}\text { ha } \\
2240 \pm 60\end{array}$ & $\begin{array}{l}2340-2290(17.3 \%) \\
2260-2150(50.9 \%)\end{array}$ & $2360-2110(95.4 \%)$ & $\begin{array}{c}\text { low possible date of strong } \\
\text { earthquake that cut and buried } \\
\text { soil layer }\end{array}$ \\
\hline $\begin{array}{l}\text { IGAN } \\
4092\end{array}$ & $\mathrm{~T} 1$ & $\begin{array}{l}\text { char coal from seismically de- } \\
\text { formed fossil soil }\end{array}$ & $\begin{array}{c}\text { CC } \\
1460 \pm 70\end{array}$ & $1420-1290(68.2 \%)$ & $1530-1280(95.4 \%)$ & $\begin{array}{c}\text { low possible date of strong } \\
\text { earthquake that deformed and } \\
\text { buried soil layer }\end{array}$ \\
\hline $\begin{array}{l}\text { IGAN } \\
4103\end{array}$ & $\mathrm{~T} 2$ & $\begin{array}{l}\text { paleosoils overlaid by colluvium } \\
\text { sediments }\end{array}$ & $\begin{array}{c}\text { ha } \\
510 \pm 60\end{array}$ & $\begin{array}{l}630-600(13.3 \%) \\
560-500(54.9 \%)\end{array}$ & $660-460(95.4 \%)$ & $\begin{array}{c}\text { period of tectonic respite and } \\
\text { soil formation at the foot of the } \\
\text { steep slope }\end{array}$ \\
\hline $\begin{array}{l}\text { IGAN } \\
4104\end{array}$ & $\mathrm{~T} 2$ & $\begin{array}{l}\text { paleosoils overlaid by colluvium } \\
\text { sediments }\end{array}$ & $\begin{array}{c}\text { ha } \\
600 \pm 60\end{array}$ & $\begin{array}{l}650-580(50.8 \%) \\
570-540(17.4 \%)\end{array}$ & $670-520(95.4 \%)$ & $\begin{array}{c}\text { period of tectonic respite and } \\
\text { soil formation at the foot of the } \\
\text { steep slope }\end{array}$ \\
\hline $\begin{array}{l}\text { IGAN } \\
4105\end{array}$ & $\mathrm{~T} 1$ & $\begin{array}{c}\text { seismically cut fossil soil exhumed } \\
\text { in rupture of the } 2003 \text { Chuya } \\
\text { earthquake }\end{array}$ & $\begin{array}{c}\text { ha } \\
950 \pm 60\end{array}$ & $930-790(68.2 \%)$ & $970-730(95.4 \%)$ & $\begin{array}{c}\text { low possible date of strong } \\
\text { earthquake that cut and buried } \\
\text { soil layer }\end{array}$ \\
\hline $\begin{array}{l}\text { IGAN } \\
4106\end{array}$ & $\mathrm{~T} 2$ & $\begin{array}{l}\text { paleosoils overlaid by colluvium } \\
\text { sediments }\end{array}$ & $\begin{array}{c}\text { ha } \\
710 \pm 70\end{array}$ & $\begin{array}{l}730-630(50.6 \%) \\
600-560(17.6 \%)\end{array}$ & $770-540(95.4 \%)$ & $\begin{array}{c}\text { period of tectonic respite and } \\
\text { soil formation at the foot of the } \\
\text { steep slope }\end{array}$ \\
\hline $\begin{array}{l}\text { SOAN } \\
8416\end{array}$ & $\mathrm{~T} 1$ & $\begin{array}{l}\text { seismically cut peat layer covered } \\
\text { lacustrine sediments with seismic } \\
\text { convolutions }\end{array}$ & $\begin{array}{c}\text { ha } \\
2040 \pm 55\end{array}$ & $\begin{array}{l}2100-2080(3.9 \%) \\
2070-1920(64.3 \%)\end{array}$ & $2150-1880(95.4 \%)$ & $\begin{array}{c}\text { low possible date of earthquake } \\
\text { that formed convolution struc- } \\
\text { tures }\end{array}$ \\
\hline $\begin{array}{l}\text { SOAN } \\
8417\end{array}$ & $\mathrm{~T} 1$ & charcoal from paleosoil layer & $\begin{array}{c}\text { Cc } \\
2755 \pm 40\end{array}$ & $2880-2780(68.2 \%)$ & $2950-2770(95.4 \%)$ & $\begin{array}{c}\text { low possible date of strong } \\
\text { earthquake that deformed and } \\
\text { buried soil layer }\end{array}$ \\
\hline $\begin{array}{l}\text { SOAN } \\
8418\end{array}$ & $\mathrm{~T} 1$ & $\begin{array}{l}\text { fossil soil with charcoal overlaid by } \\
\text { colluvium sediments }\end{array}$ & $\begin{array}{c}\text { ha } \\
2535 \pm 40\end{array}$ & $\begin{array}{c}2750-2690(26.8 \%) \\
2640-2610(9.0 \%) \\
2590-2500(32.5 \%)\end{array}$ & $2750-2480(95.4 \%)$ & $\begin{array}{l}\text { period of tectonic respite and } \\
\text { soil formation }\end{array}$ \\
\hline $\begin{array}{l}\text { SOAN } \\
8419 \\
\end{array}$ & T1 & $\begin{array}{l}\text { fossil soil with charcoal overlaid by } \\
\text { colluvium sediments }\end{array}$ & $\begin{array}{c}\text { ha } \\
3335 \pm 40\end{array}$ & $\begin{array}{l}3640-3550(48.6 \%) \\
3540-3490(19.6 \%) \\
\end{array}$ & $\begin{array}{c}3690-3660(3.9 \%) \\
3650-3460(91.5 \%) \\
\end{array}$ & $\begin{array}{c}\text { period of tectonic respite and } \\
\text { soil formation }\end{array}$ \\
\hline $\begin{array}{l}\text { SOAN } \\
8425\end{array}$ & K & $\begin{array}{c}\text { wood fragment from humified loam } \\
\text { layer overlaid by colluvium sedi- } \\
\text { ments }\end{array}$ & $\begin{array}{c}\mathbf{w} \\
845 \pm 35\end{array}$ & $790-700(68.2 \%)$ & $\begin{array}{c}900-860(6.4 \%) \\
830-810(1.1 \%) \\
800-680(87.9 \%) \\
\end{array}$ & $\begin{array}{c}\text { stabilization period of the } \\
\text { alluvial-colluvial fan at the foot } \\
\text { of the rocky slope }\end{array}$ \\
\hline $\begin{array}{l}\text { SOAN } \\
8549\end{array}$ & $\mathrm{~K}$ & $\begin{array}{l}\text { humified loam layer overlaid by } \\
\text { colluvium sediments }\end{array}$ & $\begin{array}{c}\text { ha } \\
3275 \pm 80\end{array}$ & $3590-3400(68.2 \%)$ & $3700-3340(95.4 \%)$ & $\begin{array}{l}\text { stabilization period of the } \\
\text { alluvial-colluvial fan at the foot } \\
\text { of the rocky slope }\end{array}$ \\
\hline $\begin{array}{l}\text { SOAN } \\
8658\end{array}$ & $\mathrm{~T} 1$ & $\begin{array}{l}\text { wood fragments from fossil peat } \\
\text { layer in the proximal part of the } \\
\text { giant landslide triggered by the } \\
2003 \text { Chuya earthquake }\end{array}$ & $\begin{array}{c}\text { w } \\
650 \pm 65\end{array}$ & $\begin{array}{l}670-620(31.9 \%) \\
610-550(36.3 \%)\end{array}$ & $690-530(95.4 \%)$ & $\begin{array}{l}\text { upper possible date of strong } \\
\text { earthquake that coursed peat } \\
\text { bog formation }\end{array}$ \\
\hline $\begin{array}{l}\text { SOAN } \\
8659\end{array}$ & $\mathrm{~T} 1$ & $\begin{array}{l}\text { contemporary soil overlapping } \\
\text { seismically cut paleosoils }\end{array}$ & $\begin{array}{c}\text { ha } \\
250 \pm 30\end{array}$ & $\begin{array}{l}320-280(50.2 \%) \\
170-150(18.0 \%)\end{array}$ & $\begin{array}{c}430-360(15.0 \%) \\
330-270(55.2 \%) \\
190-140(21.3 \%) \\
20-0(4.0 \%) \\
\end{array}$ & $\begin{array}{l}\text { upper possible date of strong } \\
\text { paleoearthquake }\end{array}$ \\
\hline $\begin{array}{l}\text { SOAN } \\
8663\end{array}$ & $\mathrm{~T} 1$ & $\begin{array}{l}\text { seismically cut fossil soil with } \\
\text { charcoal }\end{array}$ & $\begin{array}{c}\text { ha } \\
2380 \pm 65\end{array}$ & $\begin{array}{c}2680-2640(9.5 \%) \\
2610-2600(1.6 \%) \\
2500-2340(57.0 \%) \\
\end{array}$ & $2720-2310(95.4 \%)$ & $\begin{array}{c}\text { low possible date of strong } \\
\text { earthquake that cut and buried } \\
\text { soil layer }\end{array}$ \\
\hline $\begin{array}{l}\text { SOAN } \\
8664\end{array}$ & $\mathrm{~T} 1$ & $\begin{array}{l}\text { fossil peat layer with charcoal in } \\
\text { the proximal part of the giant } \\
\text { landslide triggered by the } 2003 \\
\text { Chuya earthquake }\end{array}$ & $\underset{1035 \pm 45}{\text { ha }}$ & $\begin{array}{l}1050-1030(4.6 \%) \\
990-910(63.6 \%)\end{array}$ & $\begin{array}{c}1060-900(87.2 \%) \\
870-800(8.2 \%)\end{array}$ & $\begin{array}{l}\text { upper possible date of strong } \\
\text { earthquake that coursed peat } \\
\text { bog formation }\end{array}$ \\
\hline $\begin{array}{l}\text { SOAN } \\
8665\end{array}$ & $\mathrm{~T} 1$ & $\begin{array}{l}\text { seismically cut fossil soil with } \\
\text { charcoal }\end{array}$ & $\begin{array}{c}\text { ha } \\
2295 \pm 40\end{array}$ & $\begin{array}{l}2360-2300(55.0 \%) \\
2230-2200(13.2 \%)\end{array}$ & $\begin{array}{l}2360-2290(59.4 \%) \\
2270-2150(36.0 \%)\end{array}$ & $\begin{array}{c}\text { low possible date of strong } \\
\text { earthquake that cut and buried } \\
\text { soil layer }\end{array}$ \\
\hline $\begin{array}{l}\text { SOAN } \\
8666\end{array}$ & $\mathrm{~T} 1$ & $\begin{array}{l}\text { wood fragments from fossil soil } \\
\text { layer }\end{array}$ & $\begin{array}{c}\mathbf{w} \\
1935 \pm 35\end{array}$ & $\begin{array}{l}1930-1860(54.5 \%) \\
1850-1820(13.7 \%)\end{array}$ & 1990-1810 (95.4\%) & $\begin{array}{l}\text { low possible date of strong } \\
\text { earthquake that deformed and } \\
\text { buried soil layer }\end{array}$ \\
\hline
\end{tabular}


Table 2. Continuation.

\begin{tabular}{|c|c|c|c|c|c|c|}
\hline \multirow[b]{2}{*}{$\begin{array}{l}\text { Sample } \\
\text { Lab. cod }\end{array}$} & \multirow[b]{2}{*}{$\begin{array}{l}\text { Location } \\
\text { Fig. } 4\end{array}$} & \multirow[b]{2}{*}{ Sample type } & \multirow[b]{2}{*}{$\begin{array}{l}{ }^{14} \mathrm{C} \text { age* } \\
\text { (BP) }\end{array}$} & \multicolumn{2}{|c|}{ Calibrated age (cal BP) } & \multirow[b]{2}{*}{ Interpretation } \\
\hline & & & & $\begin{array}{c}\text { Significance level } \\
68.2 \%\end{array}$ & $\begin{array}{c}\text { Significance level } \\
95.4 \%\end{array}$ & \\
\hline $\begin{array}{l}\text { SOAN } \\
8667\end{array}$ & $\mathrm{~T} 1$ & $\begin{array}{l}\text { wood fragments from fossil soil } \\
\text { layer }\end{array}$ & $\begin{array}{c}\mathbf{w} \\
2390 \pm 65\end{array}$ & $\begin{array}{c}2680-2640(10.5 \%) \\
2610-2590(2.3 \%) \\
2500-2340(55.4 \%) \\
\end{array}$ & $2720-2320(95.4 \%)$ & $\begin{array}{c}\text { low possible date of strong } \\
\text { earthquake that deformed and } \\
\text { buried soil layer }\end{array}$ \\
\hline $\begin{array}{l}\text { SOAN } \\
8668\end{array}$ & $\mathrm{~T} 1$ & $\begin{array}{l}\text { wood fragments from fossil soil } \\
\text { layer }\end{array}$ & $\begin{array}{c}\mathbf{w} \\
2490 \pm 35\end{array}$ & $\begin{array}{l}2720-2680(13.1 \%) \\
2640-2490(55.1 \%)\end{array}$ & $2740-2430(95.4 \%)$ & $\begin{array}{l}\text { low possible date of strong } \\
\text { earthquake that deformed and } \\
\text { buried soil layer }\end{array}$ \\
\hline $\begin{array}{l}\text { SOAN } \\
8669\end{array}$ & $\mathrm{~T} 1$ & fossil soil with charcoal & $\begin{array}{c}\text { ha } \\
2540 \pm 50\end{array}$ & $\begin{array}{c}2750-2690(25.5 \%) \\
2640-2610(8.4 \%) \\
2600-2500(34.3 \%)\end{array}$ & $2760-2460(95.4 \%)$ & $\begin{array}{l}\text { low possible date of strong } \\
\text { earthquake that interrupt soil } \\
\text { formation }\end{array}$ \\
\hline $\begin{array}{l}\text { SOAN } \\
8670\end{array}$ & $\mathrm{~T} 1$ & charcoal in sandy loams & $\begin{array}{c}\text { Cc } \\
3785 \pm 45\end{array}$ & $4240-4090(68.2 \%)$ & $\begin{array}{c}4380-4370(0.5 \%) \\
4360-4320(1.6 \%) \\
4300-4060(85.4 \%) \\
4050-3980(7.9 \%) \\
\end{array}$ & $\begin{array}{l}\text { intensification of slope } \\
\text { processes }\end{array}$ \\
\hline $\begin{array}{l}\text { SOAN } \\
8671\end{array}$ & $\mathrm{~T} 1$ & charcoal in lacustrine sediments & $\begin{array}{c}\text { cc } \\
3765 \pm 45\end{array}$ & $\begin{array}{c}4230-4080(62.5 \%) \\
4030-4010(5.7 \%)\end{array}$ & $\begin{array}{c}4290-4270(1.1 \%) \\
4260-3980(94.3 \%)\end{array}$ & $\begin{array}{l}\text { upper possible date of strong } \\
\text { earthquake that coursed lake } \\
\text { formation }\end{array}$ \\
\hline $\begin{array}{l}\text { SOAN } \\
8672\end{array}$ & $\mathrm{~T} 1$ & buried peat & $\begin{array}{c}\text { ha } \\
3590 \pm 45\end{array}$ & $\begin{array}{l}3970-3940(11.2 \%) \\
3930-3830(57.0 \%)\end{array}$ & $\begin{array}{c}4080-4040(3.3 \%) \\
4000-3810(84.4 \%) \\
3800-3720(7.7 \%)\end{array}$ & $\begin{array}{l}\text { upper possible date of strong } \\
\text { earthquake that coursed peat } \\
\text { bog formation }\end{array}$ \\
\hline $\begin{array}{l}\text { SOAN } \\
8673\end{array}$ & T1 & $\begin{array}{l}\text { buried peat layer in the proximal } \\
\text { part of the giant landslide triggered } \\
\text { by the } 2003 \text { Chuya earthquake }\end{array}$ & $\begin{array}{c}\text { ha } \\
770 \pm 40\end{array}$ & $730-670(68.2 \%)$ & $770-660(95.4 \%)$ & $\begin{array}{l}\text { upper possible date of strong } \\
\text { earthquake that coursed peat } \\
\text { bog formation }\end{array}$ \\
\hline
\end{tabular}

${ }^{*}$ Radiocarbon analysis was made on cc - charcoal, ha - humic acid, w - wood.

(IGAN 4105) and the age of undistorted fossil soil covering them is $430-140$ cal BP (SOAN 8659). The dendrochronologically obtained earthquake age lies inside the time limits determined by radiocarbon dating.

Radiocarbon dates of buried peat layers as well as fragment of tree trunk in lacustrine deposits returns the upper possible age of earthquakes that coursed peat bog or lake formation in the proximal part of previously existed at the same place paleolandslide (690-530, 770-660, 1060-800, 4080-3720, 4290-3980 cal BP (SOAN 8658,
8673, 8664, 8672, 8671)). In section (Fig. 8; Fig. 3, location 1) the seismically cut buried peat layer covers lacustrine sediments with seismic convolutions and underlie deposits of younger lake. Marking the period of tectonic quiescence and peat bog formation the age of peat (2150 1880 cal BP (SOAN 8416)) also indicate time period between two possible prehistoric seismic events. One of them stipulated developing of seismic convolutions and another caused cutting of peat layer and lake formation.
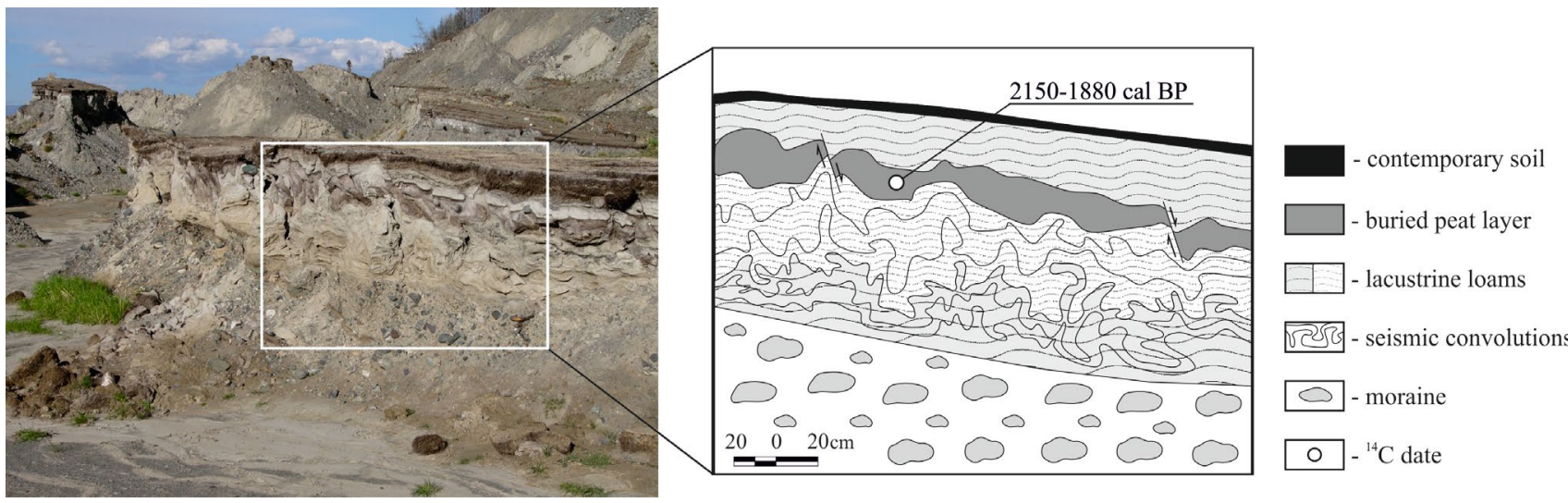

Fig. 8. Section of lacustrine sediments with the peat layer in the Taldura valley (location 1 in Fig. 3). 
Deposits exhumed in an outcrop in one of the scarps of the giant landslide triggered by the 2003 Chuya earthquake in the Taldura valley indicate a complicated slope sedimentation patterns. A section of redeposited slope material with broken and deformed thin soil layers stuffed with charcoals and charred tree fragments overlays brownish sandy loams above moraines and layer of buried soil of 2760-2460 cal BP (SOAN 8669) (Fig. 3, location 2). Radiocarbon dates of organic material from deformed layers of fossil soils evidence for at least two periods (about 1400 and $2600 \mathrm{cal} \mathrm{BP}$ ) of abrupt intensification of slope activity which can be related to seismic events. Trees with the age about 1400 cal BP are buried by older deposits with the charcoals and tree fragments (SOAN 8417, 8666, 8667). Intensification of slope activity about $2600 \mathrm{cal}$ BP is evidenced by the age of tree fragment in colluvium sediments (SOAN 8668). Seismically deformed paleosoils from another outcrop in the same part of the landslide $(2750-2480,3690-3460$ cal BP (SOAN 8418, 8419)) support the earthquake occurred about $2600 \mathrm{cal}$ BP and allows suggesting presence of another more old seismic event about $3500 \mathrm{cal}$ BP.

Fossil soils buried by colluvium at the foot of steep slopes mark periods of tectonic quiescence and soil formation which were altered by intensive slope mass movements. Ages of these fossil soils could be also interpreted as the upper possible ages of earthquakes that triggered intensive displacement of slope strata. Several such estimates were revealed from radiocarbon dates of fossil soils in outcrops in the upper part of the Taldura valley $(660-460,670-520,770-540$ cal BP (IGAN 4103, 4104, 4106) (Fig. 4 - T2)).

Radiocarbon dates of fossil soils buried by talus fans at the foot of the Kurai range in Kurai intermountain depression (900-680, 3700-3340 cal BP (SOAN 8425, 8549) (Fig. 4 - K)) also return the upper ages of possible past seismic events that caused soils inhumation.

\section{DISCUSSION}

Successful implementation of tree-ring analysis in paleoseismology implies basing seismic origin of studied tree-ring anomalies. Despite of seismic reasons, changes in growth rate can be also caused by many environmental factors and nonseismic geomorphic disturbances. To conduct effective dendrochronological study Jacoby (McCalpin, 2009) suggests the following requirements: 1) damaged trees should be confined to the rupture zone;

2) diverse evidences of paleoearthquake must exist; and 3) muster chronology should be developed from trees unaffected by the paleoearthquake.

Seismic genesis of studied landforms is proved by applying a number of criteria (Nepop and Agatova, 2008). Location of forest stand in an area affected by earthquake induced slope processes is also evidenced by analyzing ground effects of the 2003 Chuya earthquake. Local muster TRC was developed from undamaged trees and from parts of tree trunks unaffected by rock-falls, thus it gives an opportunity to calculate the precise age of detected growth anomalies. Further analysis of spatial distribution of injured trees, a number of traumatic disturbances of tree-rings and their location at different height within the tree trunk, as well as comparison these results with the distribution patterns of traumatic injuries caused by the 2003 Chuya earthquake, allowed to suggest the date of seismic event, which was a trigger of rock-falls. It should be mentioned that at first, this dendrochronologically obtained date of abrupt intensification of rock-falls was just supposed date of strong earthquake. Later it was verified by paleoseismogeological data and radiocarbon dating.

Twenty-five radiocarbon dates and results of tree-ring analysis most completely cover the period from about 4000 cal BP till present time. We have obtained just few radiocarbon dates of ground effects related to strong earthquakes occurred in the first half of the Holocene. This can be explained by worse preservation of surface effects and other features induced by ancient shocks. So in this paper we present dating results only for the last 4000 years.

It should be also noted that accuracy of the radiocarbon method doesn't allow estimating the precise earthquake ages, but it is acceptable for reliable distinguishing the time of formation of ground effects associated with different earthquakes. This is important for marking time intervals for single seismic events and then for calculating the recurrence interval of strong earthquakes.

As it was shown above, dendrochronologically obtained date (AD 1532) of strong medieval earthquake was verified by radiocarbon dating. Moreover, radiocarbon age of paleosoils buried in colluvium wedge within the modern landslide in the Taldura valley is interpreted as a date of strong prehistoric earthquake $(370 \pm 30$ BP IGAN 3007 (Rogozhin et al., 2007)) and also supports this thesis. After calibration it falls within the time interval $\mathrm{AD}$ 1440-1640 (1440-1530 (55.0\%) or 1550-1640 (40.4\%)). Another evidence of this medieval seismic event was detected within the southern flank of the Central Kurai neotectonic foreberg. $1.5 \mathrm{~m}$ scarp of an active fault was dissected by trenches (Rogozhin and Platonova, 2002). A cross section of ancient fault area represents a set of three-four steep and more flat reverse faults. Radiocarbon ages (324 \pm 30 BP (IGAN 1692) and $345 \pm 30$ BP (IGAN 1702)) of wooden splinters and charcoals from peat layers, which were cut by these reverse faults, indicate the formation of the ancient fault area after AD 1460.

Thus geological evidences of the strong medieval earthquake are presented $i$ ) at the cross points of the fault borders of the Chagan-Uzun massif with the fault borders of the Chuya intermountain depression and South Chuya range; $i$ ) within the inner structure of the Chagan-Uzun massif along its northern border (in the Arydjan valley); and iii) at the southern flank of the Central Kurai neotectonic foreberg. The traced length of rapture zone about 
70-75 km allows to assume the magnitude of this seismic event as about 7.5 (Rogozhin and Platonova, 2002).

The obtained ages of the oldest trees and estimated minimal ages of the largest seismically induced landslides in the Arydjan valley don't allow clearly correlate them with the known earthquakes identified by region paleoseismogeological data. Most likely they are related to the paleoearthquakes that caused ruptures and fossil soils deformations in the Kuskunur valley and in the Uzuk stow (Kuskunur - Taldura watershed). Paleosoils in colluvium wedges and pressure ridges (compressional moletracks) buried by coarse-grained material have radiocarbon ages $1280 \pm 30,1160 \pm 30,1100 \pm 30 \mathrm{BP}$ (IGAN 2818, 2980, 2983) (Rogozhin et al., 2007). Fossil soils in colluvium wedge along tectonic scrap at the foothill of the Central Kurai neotectonic foreberg has similar radiocarbon age $1040 \pm 80$ BP (GIN 9082) and indicate the date of strong prehistoric earthquake (Rogozhin and Platonova, 2002). Calibrated ages indicate that strong past earthquakes, which caused these surface disturbances, struck the SE Altai between AD 660 and AD 1170.

Our own paleoseismogeological investigations also support this thesis. The radiocarbon ages of fossil soil with char coals and buried peat layer in the proximal part of the largest landslide triggered by the 2003 Chuya earthquake in the Taldura valley $(1035 \pm 45,770 \pm 40 \mathrm{BP}$ (SOAN 8664, 8673)) return the minimal possible age of prehistoric earthquake which coursed the lake and peat bog formation. The radiocarbon age of char coal from seismically deformed fossil soil within this landslide is $1460 \pm 70$ BP (IGAN 4092). Thus we can assert that strong earthquakes struck the SE Altai between AD 420 and AD 1290. Probably one of these earthquakes triggered studied landslides in the Arydjan valley.

Our analysis of unknown ground effects of past seismic events indicates that strong earthquakes occurred about 600-700, 1300-1500, 2400-2700, 3400-3700 and $3800-4200$ cal BP. This conclusion supports previously published data on high regional seismicity (Rogozhin and Platonova, 2002 and Rogozhin et al., 2007, 2008) and argues for the repeated reactivation of the same earthquake source zones during the Holocene. Obtained radiocarbon dates together with previously published ones clarify the chronology of seismic events within the SE Altai (Fig. 9). It should be mentioned that due to specific problems of applying radiocarbon technique for dating young events (Wagner, 1998) several too young radiocarbon dates (about 200 years) presented in some publications (Rogozhin and Platonova, 2002 and Rogozhin et al., 2007, 2008) couldn't be utilized for reliable time distinguishing of ground effects for the seismic events of the recent past. Thus reconstructed dates of prehistoric seismic events together with the dendrochronologically obtained age of the medieval earthquake allow estimating the recurrence interval of strong earthquakes in the SE Altai as about 400 years for the last 4000 years.
Paleoseismogeological investigations in adjusted seismically active areas of the Mongolian Altai reveal traces of several more strong $(M \geq 8)$ earthquakes. In the epicenter zone of the 1931 Fuyun earthquake $(M=8.0)$ at the western part of the Mongolian Altai, the historical and paleoseismological data evidence for presence of five such earthquakes over the last 10000 years (Shumo et al., 1996 and Rogozhin et al., 2012). Five strongest seismic events with $M \geq 8$ over the last 7500 years, including the 1761 Great Mongolian earthquake, were also reconstructed in the eastern part of the Mongolian Altai (Rogozhin et al., 2013). The specified recurrence interval of strong earthquakes for the SE Altai correlates with these data published for neighboring areas of Mongolian Altai. It is shorter than intervals for adjusted seismically active areas of the Mongolian Altai due to smaller magnitudes of strongest shocks.

\section{CONCLUSION}

Paleoseismogeological researches within the pleistoseist zone of the 2003 Chuya earthquake, SE Altai, reviled unknown evidences of strong past seismic events. Seismically deformed fossil soils overlaid by undistorted ones, soils and peat layers buried by colluvium at the foot of the slopes, organic material from colluvium wedges and overlaid by pressure ridges, paleopeats affected by seismic convolutions were studied in newly arisen and renewed outcrops at the southern fault boundary of the Chagan-Uzun massif in the Taldura valley. Twenty-five radiocarbon dates indicate six earthquakes that stroke SE Altai during the last 4000 years and mark time limits of these seismic events: $300-500,600-700,1300-1500$, 2400-2700, 3400-3700, 3800-4200 cal BP.

Perspectives of applying tree-ring analysis in paleoseismogeological researches within the SE Altai were demonstrated by studying seismically triggered landslides

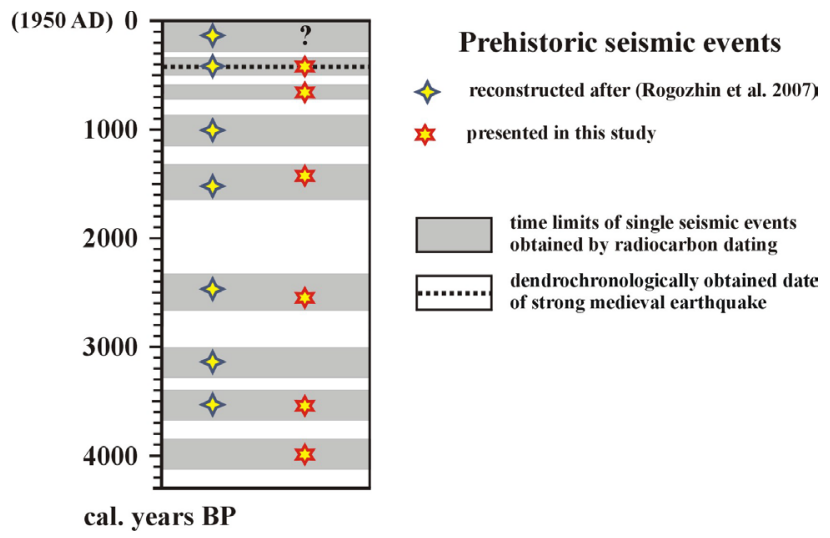

Fig. 9. Reconstructed dates of strong prehistoric earthquakes within the SE Altai, obtained by radiocarbon method and dendrochronological analysis. 
in the northern part of the Chagan-Uzun massif in the Arydjan valley. In addition to estimating the germination ages of trees growing on the bare surfaces of these landslides, analysis of wood penetrating injuries in the individual tree ring series was suggested for dating earthquake induced paleorock-falls. Spatial distribution of injured trees, a number of traumatic disturbances of treerings and their location at different height within the tree trunk, as well as comparison of these results with the distribution patterns of traumatic injuries caused by the 2003 Chuya earthquake, was used as criteria of seismic origin of past rock-falls. Dendrochronologically obtained date of abrupt intensifications of rock-falls was considered as supposed date of strong medieval earthquake, which was verified by radiocarbon dating and alternative proxy data. It allows estimating the precise date (AD 1532) for seismic event which was limited 300-500 cal $\mathrm{BP}$ by radiocarbon analysis.

Studied effects of strong prehistoric earthquakes preserved in the northern part of the Chagan-Uzun massif, and along fault boundary between Chuya depression and North Chuya range supports thesis about repeated reactivations of the same earthquake source zones within the SE Altai.

Obtained dendrochronological and radiocarbon dates together with the previously published data confirm the high occurrence of strong $(M \geq 7)$ earthquakes in the region. Generally, eight such seismic events were revealed in the region during last 4000 years. Specified recurrence interval of strong earthquakes for this time interval is about 400 years. This data argues for the high Holocene seismicity of the SE Altai and defines the Chagan-Uzun massif, which separates Chuya and Kurai intermountain depressions, as one of the major regional seismogenic structure.

\section{ACKNOWLEDGEMENTS}

We would like to thank I.Yu. Ovchinnikov (IGM SB RAS, Novosibirsk) and E.P. Zazovskaya (IG RAN, Moscow) for radiocarbon dating. Dendrochronological age estimations were done by V.S. Myglan and V.V. Barinov (Siberian Federal University, Krasnoyarsk) and were funded by Russian Science Foundation (grant 15-1430011). Four anonymous reviewers are kindly thanked for their detailed and constructive reviews that improved style and content of the manuscript. The study was supported by state assignment project (0330-2016-0015) and partly funded by Russian Foundation for Basic Researches (grants 16-05-001035; 18-05-00998).

\section{REFERENCES}

Agatova AR, Nepop RK and Vysotsky EM, 2006. Seismogravitacionnye paleodislokacii v doline reki Chagan (Yugo-Vostochnyj Altai, Rossija) (Seismogravitational paleodeformations in Chagan river valley (SE Altai, Russia)). Geomorfologiya 4: 53-62 (in Russian).
Agatova AR, Nepop RK, Slyusarenko IYu, Myglan VS, Nazarov AN and Barinov VV, 2014a. Glacier dynamics, palaeohydrological changes and seismicity in southeastern Altai (Russia) and their influence on human occupation during the last 3000 years. Quaternary International 324: 6-19, DOI 10.1016/j.quaint.2013.07.018.

Agatova AR, Nepop RK, Barinov VV, Nazarov AN and Myglan VS, 2014b. The first dating of strong Holocene earthquakes in Gorny Altai using long-term tree-ring chronologies. Russian Geology and Geophysics 55: 1059-1067, DOI 10.1016/j.rgg.2014.08.002.

Barinov VV, Myglan VS, Nazarov AN, Vaganov EA, Agatova AR and Nepop RK, 2016. Extreme climatic events in the Altai Republic according to dendrochronological data. Biology Bulletin 43(2): 152-161, DOI 10.1134/S1062359016020023.

Bekker MF, 2004. Spatial variation in the response of tree rings to normal faulting during the Hebgen Lake Earthquake, Southwestern Montana, USA. Dendrochronologia 22: 53-59.

Bronk Ramsey C, 2009. Bayesian analysis of radiocarbon dates. Radiocarbon 51(1): 337-360.

Burbank DW and Anderson RS, 2001. Tectonic Geomorphology. Oxford, UK, Blackwell Publishing: 274pp.

Butvilovsky VV, 1993. Paleogeografiya poslednego oledenenija $i$ golocena Altaja: Sobytijno-Katastroficheskaja model' (Paleogeography of the Last Glaciation and the Holocene of Altai: a Catastrophic Events Model). Tomsk, Tomsk University Press: 253pp (in Russian).

Cook ER and Krusic PJ, 2008. A tree-ring standardization program based on detrending and autoregressive time series modeling, with interactive graphics (ARSTAN). http://www.ldeo.columbia.edu/res/fac/trl/public/publicSoftware.ht $\mathrm{ml}$.

Deev EV, Zolnikov ID and Gus'kov SA, 2009. Seismites in Quaternary sediments of southeastern Altai. Russian Geology and Geophysics 50(6): 546-561, DOI 10.1016/j.rgg.2008.10.004.

Devyatkin EV, 1965. Kajnozojskie otlozhenija $i$ neotektonika Yugovostochnogo Altaja (Cenozoic deposits and neotectonics of Southeastern Altai). Moscow, USSR Academy of Science: 244pp (in Russian).

Emanov AA, Leskova VE, Emanov AF and Fateev AV, 2009. Elements of the structure and phase of development of the Chuya earthquake aftershock. Fizicheskaya Mezomekhanika 12(1): 29-36.

Friedman JM, Vincent KR and Shafroth PB, 2005. Dating floodplain sediments using tree-ring response to burial. Earth Surface Processes and Landforms 30: 1077-1091, DOI 10.1002/esp.1263.

Fritts HC, 1976. Tree-Rings and Climate, Academic, San Diego, Calif. $567 \mathrm{pp}$.

Holmes RL, 1983. Computer-assisted quality control in tree-ring dating and measurement. Tree-Ring Bulletin 44: 69-75.

Hupp CR, Osterkamp WR and Thornton JL, 1987. Dendrogeomorphic Evidence and Dating of Recent Debris Flows on Mount Shasta, Northern California. US Geological Survey Professional Paper 1396-B

Jacoby GC, 1997. Application of tree-ring analysis to paleoseismology. Reviews of Geophysics 35: 109-124, DOI 10.1029/96RG03526.

Keefer DK, 2002. Investigating landslides caused by earthquakes - a historical review. Surveys in Geophysics 23: 473-510, DOI 10.1023/A:1021274710840.

Kirnos DP, Kharin DA and Shebalin NV, 1961. History of instrumental seismology in the USSR, in: Vvedenskaya NA and Kondorskaya NV (Eds.), Earthquakes in the USSR. Moscow, USSR Academy of Science: 9-66 (in Russian).

Lundström T, Jonsson MJ, Volkwein A and Stoffel M, 2009. Reactions and energy absorption of trees subject to rockfall: A detailed assessment using a new experimental method. Tree Physiology 29: 345-359, DOI 10.1093/treephys/tpn030.

McAuliffe JR, Scuderi LA and McFadden LD, 2006. Tree-ring record of hillslope erosion and valley floor dynamics: Landscape responses to climate variation during the last $400 \mathrm{yr}$ in the Colorado Plateau, Northeastern Arizona. Global and Planetary Change 50: 184-201, DOI 10.1016/j.gloplacha.2005.12.003.

McCalpin JP, 2009. Ed. Paleoseismology. Vol. 95. Academic press. 
Myglan VS, Ovchinnikov DV, Vaganov EA, Bykov NI, Gerasimova OV, Sidorova OV and Silkin PP, 2009. Postroenie 1772-letnei drevesno-kol'cevoj hronologii dlja territorii respubliki Altai (Construction of 1772-year tree ring width chronology for Altay Republic). Izvestiya RAN. Seriya Geograficheskaya 6: 70-77 (in Russian).

Nazarov AN and Myglan VS, 2012. The Possibility of construction of the 6000-year chronology for Siberian Pine in the Central Altai. Journal of Siberian Federal University. Biology 5(1): 70-88.

Narozny YuK and Osipov AV, 1999. Oroklimaticheskie usloviya oledeneniya Central'nogo Altja (Oroclimatic conditions of the Central Altai glaciations). Izvestija Russkogo Geograficheskogo Obschestva 131(3): 49-57 (in Russian).

Nepop RK and Agatova AR, 2008. Estimating magnitudes of prehistoric earthquakes from landslide data: first experience in southeastern Altai. Russian Geology and Geophysics 49(2): 144-151, DOI 10.1016/j.rgg.2007.06.013.

Ovchinnikov DV, Panyushkina IP and Adamenko MF, 2002. Thousandyear tree-ring chronology of Larch in Gorny Altai and its use for the reconstruction of summer temperatures. Geography and natural resources 1: 102-108 (in Russian).

Okishev PA, 1982. Dinamika oledenenija Altaja v pozdnem Pleistocene $i$ golocene (The Dynamics of Glaciation in Altai during the Late Pleistocene and Holocene). Tomsk, Tomsk University Press: 210pp (in Russian).

Novikov IS, 2004. Morfotektonika Altaja (Morphotectonics of Altai). Novosibirsk, SB RAS Publisher: 313pp (in Russian).

Page RA, 1970. Dating episodes of faulting from tree rings - Effects of the 1958 rupture of the Fairweather fault on tree growth. Geological Society of America Bulletin 81: 3085-3094.

Reimer PJ, Bard E, Bayliss A, Beck JW, Blackwell PG, Bronk Ramsey C, Buck CE, Cheng H, Edwards RL, Friedrich M, Grootes PM, Guilderson TP, Haflidason H, Hajdas I, Hatté C, Heaton TJ, Hogg AG, Hughen KA, Kaiser KF, Kromer B, Manning SW, Niu M, Reimer RW, Richards DA, Scott EM, Southon JR, Turney CSM and Van Der Plicht J, 2013. IntCal13 and Marine13 radiocarbon age calibration curves $0-50,000$ years cal BP. Radiocarbon 55(4): $1869-1887$.

Reisner GI and Ioganson LI, 1996. Ocenka seismicheskogo potenciala Altaja s primeneniem vneregional'nogo seismotektonicheskogo metoda (Estimating the seismic potential of Altai using a universal seismotectonic method). Bull., Federal System for Seismology and Earthquake Prediction, Moscow, OIFZ RAN Publisher, 3(1/2): 90-95 (in Russian).

Rinn F, 1996. TSAP V. 3.6 Reference Manual: Computer Program for Tree-Rings Analysis and Presentation, Heidelberg: Frank Rinn Distrib.

Rogozhin EA and Platonova SG, 2002. Ochagovaye zony sil'nyh zemletrjasenij Gornogo Altaja v Golocene (Strong earthquake source zones of Gorny Altai in the Holocene). Moscow, UIPE RAS: 130pp (in Russian).

Rogozhin EA, Ovsyuchenko AN, Marahanov AV and Ushanova EA, 2007. Tectonic setting and geological manifestations of the 2003 Altai earthquake. Geotectonics 47(2): 87-104, DOI 10.1134/S001685210702001X.

Rogozhin EA, Ovsyuchenko AN and Marahanov AV, 2008. Major earthquakes of the southern Gorny Altai in the Holocene. Izvestiya. Physics Solid Earth 44(6): 469-486.

Rogozhin EA, Sheng Zhung and Rodina SN, 2012. Sopostavlenie sejsmotektonicheskih osobennostej Gornogo i Mongol'skogo Altaja (Correlation of seismotectonic features of the Gorny and Mongolian Altay). Issues of Engineering Seismology 39(3): 5-20 (in Russian).

Rogozhin EA, Lar'kov AS, Demberel S and Battulga B, 2013. Recurrence of strong earthquakes in the active Hovd fault zone, Mongolian Altay. Geotectonics 47(5): 340-350, DOI 10.1134/S0016852113050051.

Ruzhich VV, San'kov VA and Dneprovskii YI, 1982. The dendrochronological dating of seismogenic ruptures in the Stanovoi Highland. Soviet Geology and Geophysics. English Translation 23(8): 57-63.

Sheppard PR and Jacoby GC, 1989. Application of tree ring analysis to paleoseismology - 2 case studies. Geology 17: 226-229, DOI 10.1130/0091-7613(1989)017<0226:AOTRAT>2.3.CO;2.

Shiyatov SG, Vaganov EA, Kirdjanov AV, Kruglov VB, Mazepa VS, Naurzbaev MM and Khantemirov RM, 2000. Metody Dendrochronologii. Chast' I (Methods of dendrochronology. Part I). Krasnojarsk, Krasnojarsk University press: 80pp (in Russian).

Shumo Ge, Mexiang Bo, Fuwan Zheng and Fuzhong Luo, 1996. The Koktogay_Ertay Fault, Xinjiang, China. Journal of earthquake prediction research 5(4): 470-506.

Solonenko VP, 1973. Zemletrjasenija i rel'ef (Earthquakes and relief). Geomorfologiya, 4: 3-13 (in Russian).

Stoffel M and Bollschweiler M, 2008. Tree-ring analysis in natural hazards research - an overview. Natural hazards and Earth system Sciences 8: 187-202, DOI 10.5194/nhess-8-187-2008.

Stoffel M and Corona C, 2014. Dendroecological Dating of Geomorphic Disturbance in Trees. Tree-Ring Research 70(1): 3 20, DOI 10.3959/1536-1098-70.1.3.

Strunk H, 1997. Dating of geomorphological processes using dendrogeomorphological methods. Catena 31: 137-151, DOI 10.1016/S0341-8162(97)00031-3.

Tainik AV, Myglan VS, Barinov VV, Nazarov AN, Agatova AR and Nepop RK, 2015. The growth of Siberian larch (Larix sibirica Ldb.) at the upper forest boundary in the Altai Republic, Izvestiya RAN. Seriya Geograficheskaya 6: 75-85.

Trappmann D and Stoffel M, 2013. Counting scars on tree stems to assess rockfall hazards: A low effort approach, but how reliable? Geomorphology $\quad 180-181: \quad 180-186, \quad$ DOI 10.1016/j.geomorph.2012.10.009.

Wagner GA, 1998. Age Determination of Young Rocks and Artifacts. Berlin Heidelberg, Springer: 466pp.

Zhalkovsky ND and Muchnaya VI, 1975. Raspredelenie zemletrjasenij po energii I seismicheskaja aktivnost' Altae-Sajanskoj oblasti (Energy distribution of earthquakes and seismic activity in the AltaiSayan area). In: Chernov GA, ed., Seismicity of the Altai-Sayan area. Novosibirsk, Nauka, 5-15pp. (in Russian).

Zhalkovsky ND and Muchnaya VI, 1978. Katalog sil'nyh zemletrjasenij Altae-Sajanskogo regiona ( $\mathrm{K} \geq 12 ; \mathrm{M} \geq 4.5$ ) (Catalog of large earthquakes in the Altai-Sayan area $(\mathrm{K} \geq 12 ; \mathrm{M} \geq 4.5))$. In: Solonenko VP and Nikolaev VA, eds., Seismogeology of the Eastern Altai-Sayan Mountain Province. Novosibirsk, Nauka, 15$27 \mathrm{pp}$. (in Russian).

Zhalkovsky ND, Kuchai OA and Muchnaya VI, 1995. Seismichnost' i nekotorye harakteristiki naprjazhennogo sostojanija zemnoj kory Altae-Sajanskoj oblasti (Seismicity and some characteristics of the stress state of the Earth's crust in the Altai-Sayan region) Russian Geology and Geophysics 36(10): 20-30 (in Russian). 